\title{
Balkan ophiolite-related geology
}

\author{
Annie Rassios • Alastair Robertson
}

Published online: 28 July 2012

(C) Springer-Verlag 2012

The present thematic set of papers resulted from the field symposium "Ophiolites 2008: Link between the Mesohellenic Ophiolites and Pelagonian Margin," which was held September 14-20 in West Macedonia and Thessaly, Greece. This was the second of a series of field meetings aiming to provide international researchers with an opportunity to examine the ophiolitic rocks and related geology of the Balkan region. The field localities studied during the field trip within mainland Greece included sites that are important to the development of plate tectonic theory.

The geologic pioneer in the region was Jan Brunn (1907-2006) who in 1938 documented the contact relations between the Vourinos ophiolite and Pelagonian continental margin along the Aliakmon River, noting later that this "might be the most complete and significant outcrop of the base of ophiolites in the world." The same contact was critical in the development of the concept of an ophiolitic metamorphic sole by Jay Zimmerman in the late 1960s and the definition of ophiolite as oceanic lithosphere by Eldridge Moores during the same period. Significant parts of this contact zone are to be flooded with the completion of the Ilariona Hydroelectric dam. As a result, the Public Power Corporation of Greece sponsored an international educational program, the Aliakmon Project (2005-2009), to aid in a final scientific documentation of this area as a historic geologic site. Overseen by the Institute of Geology and Mineral Exploration (IGME), most of the research was

\footnotetext{
A. Rassios ( $\square)$

Institute of Geology and Mineral Exploration, Kozani, Greece e-mail: rassannie@gmail.com
}

\author{
A. Robertson \\ University of Edinburgh, Edinburgh, UK
}

conducted by a team of over fifty international geology students, directed by Dr Annie Rassios, as a means of passing the heritage of this site to future generations.

The symposium field trip showcased this legacy of Greek geology as well as aspects of the regional geology essential to its interpretation. The informative guidebook is still freely available (Rassios et al. 2008).

Over fifty researchers presented papers and posters during the field trip. These summarized what is known from the region and stimulated discussion on various geological interpretations and models, some seemingly contradictory. The ophiolites of Koziakas, Vourinos, and the Pindos were visited to demonstrate the processes of oceanic lithosphere formation and the means of ophiolite obduction/emplacement. Sites along the west Pelagonian margin were also visited to exemplify the nature of the underlying Pelagonian continent and its pre-ophiolite rifted margin. Key features of the pre-ophiolite rift geology and the ophiolite lithosphere genesis and obduction are all clearly demonstrated within the valley of the Aliakmon River that was a focus of the field trip.

Our understanding of the ophiolites within the regional geological setting is still evolving, and we hope that this set of papers will stimulate renewed research in this region and its world-class geology.

A subset of the papers presented are published in the present volume. One wide-ranging overview paper given at the meeting has since been published elsewhere (Robertson 2012), while another that is included here was contributed after the meeting. Together, these papers highlight some essential observations and interpretations within the complex regional geology of the Balkans. However, they also highlight the significant differences in interpretation that still exist especially concerning the nature and location of the ophiolitic basin from which the ophiolites were derived. 
1. Accurate zircon dating of the regional basement provides important constraints in the regional geological framework for ophiolite genesis and emplacement. Here, Himmerkus and others utilize their new age results to develop new tectonic models for the timing and evolution of the host Pelagonian margin.

2. Osvart and others provide new radiolarian biochronological evidence for the Triassic deep-sea sedimentary rocks associated with the ophiolites in the north Pindos and Othrys areas. The results help constrain the timing of opening of the precursor ocean in the region.

3. Kiss clarifies the meaning and role of "peperites" as a special diagnostic tool for improved strato-tectonic modeling relevant to a regional Neotethyan rifting model for the Dinarides and various parts of Greece.

4. Merlini and others provide significant new mineralogical observations on the alteration of chromite. They draw on this information to provide a "window" into an otherwise unobservable period in ophiolitic evolution, namely the temperature conditions of the alteration process that coincides with the latest stage of ductile deformation but preceding brittle emplacement.

5. Robertson and others provide new data and interpretations concerning the development of syn- and post-ophiolite emplacement sedimentary successions exposed in southern Albanian. These help constrain the timing and mechanism of emplacement of the Balkan ophiolites more widely.

6. Through a wide-ranging review, Chanier and others develop a new hypothesis for the single-ocean (Maliac) derivation of the Greek ophiolites. Their presentation of the strato-tectonic data reveals the difficulty of incorporating sometimes contradictory information into a single uniform model and is likely to stimulate further study.

\section{References}

Rassios A, Smith A, Kostopoulos D (2008) GUIDEBOOK Ophiolites 2008: Link between the Mesohellenic Ophiolites and Pelagonian Margin, West Thessaly and West Macedonia, Greece. Institute of Geology and Mineral Exploration, 88p. Reprinted on-line in Virtual Explorer, 2009: http://virtualexplorer.com.au/journal/ 2009/34

Robertson AHF (2012) Late Palaeozoic-Cenozoic tectonic development of Greece and Albania in the context of alternative reconstructions of Tethys in the Eastern Mediterranean region. Int Geol Rev 54(4):373-454 